\title{
DEVELOPMENT OF AN AGGREGATED SOCIAL INCLUSION INDICATOR. DISPARITIES IN THE EUROPEAN UNION ON INCLUSION/EXCLUSION SOCIAL DETERMINED WITH SOCIAL INCLUSION INDEX
}

\author{
Dorel-Mihai PARASCHIV ${ }^{*}$, Daniela-Ioana MANEA², \\ Emilia ȚIȚAN ${ }^{3}$, Mihaela MIHAI ${ }^{4}$ \\ ${ }^{1}$ The Department of International Business and Economics, \\ The Faculty of International Business and Economics, The Bucharest University of Economic Studies, \\ Romana Square, No. 6, 010374 Bucharest, Romania \\ 2,3,4 The Department of Statistics and Econometrics, The Faculty of Economic Cybernetics, \\ Statistics and Informatics, The Bucharest University of Economic Studies, Romana Square, \\ No. 6, 010374 Bucharest, Romania
}

Received 09 October 2020; accepted 25 April 2021; first published online 06 October 2021

\begin{abstract}
When we mention social inclusion, most of us think of political participation, social rights, civil liberties, equal access to race, ethnicity and gender, access to social services and the labour market, basically to a broader concept than social development. Social inclusion is a concept that can actually be defined, which means it can probably be measured. On this basis, a continuous effort is being made to measure the social inclusion elements, so the results can be used to build new indicators that help measure the multiple dimensions of social inclusion: The Social Inclusion Index, the Human Opportunity Index. This paper presents the development, based on multivariate data analysis techniques and methods, of an aggregated indicator of social inclusion for the member countries of the European Union which, besides the traditional variables (GDP), also measures the factors related to civil and political rights, women's rights or perception of the LGBT community.
\end{abstract}

Keywords: social inclusion, Cluster Analysis, Factorial Analysis, Analysis of the Principal Components.

JEL Classification: B55, C38, C43.

\section{Introduction}

Social inclusion is a complex phenomenon and cannot be described directly, and due to its' multidimensionality, to use a relatively large number of indicators should be used, in order to study it. In the study of the Social Inclusion Indicator calculated for the countries of the

\footnotetext{
*Corresponding author. E-mail: dorel.paraschiv@ase.ro
} 
European Union (EU), the primary indicators take the form of quantitative statistical variables, which are neither independent, nor we can say they are perfectly superimposed. This derives from the simple fact that all primary indicators address aspects of reality. The effect of partial overlaps can only be redundant information contained in the variable system.

Compared to social exclusion, which embeds a certain theoretical understanding of the processes where people become marginalized in society, the theoretical framework regarding the concept of social inclusion is much narrower and has to be reformulated according to idealized definitions or statements like that of Fraser: "Social inclusion must come down to somewhere to live, something to do and someone to love. It's as simple- and as complicatedas that" (Fraser, 2003, as cited in Grove, 2008, p. 2; Fraser, 2003).

Other definitions complement this idealism, describing social inclusion as a proactive approach where all people and groups in society are appreciated, can live with dignity and their basic needs are met (Freiler, 2002; Mitchell \& Shillington, 2002; Cushing \& Roeher Institute, 2003); sometimes adding the tautological label that social inclusion involves a focus on actions that contribute to the conditions of social inclusion. In 2007, Spandler draws attention to the concept of social inclusion as a phenomenon of paradoxical demand expressed on one hand as a "real demand to address the consequences of social inequality", and at the same time becomes a doctrine that includes "a different kind of people with ... problems that are subject to moral and social regulation".

All of these set inclusion and exclusion on the same level. In general, when social inclusion was conceptualized in academic speech, it was only in relation (or opposition) to social exclusion (Labonte, 2004; Cameron, 2006; Rawal, 2008), as the two concepts were considered inseparable parts of the same theory sometimes even represented in shorthand as "SE/SI"). Normally, the resulting political talk on social inclusion tends to focus on processes or factors that would reduce exclusion (Cameron, 2006).

For example, the European Union (Council of the European Union..., 2004, p. 8) defines social inclusion as a process ensuring that people at risk of exclusion "get the opportunities and resources to fully participate in economic, social and cultural life and enjoy a standard life and a level of well-being considered normal in the society in which they live". While reducing the two concepts to one could simplify this particular literature or the empirical one on social inclusion, this idea is barely suggested. Sustainable development includes three major areas: economic, social and environmental being identified, in the literature, a number of methods of analysis to quantify the three dimensions, such as composite indices (Botha et al., 2020). However, when we refer to social inclusion as a result of economic development, it is essential that one of the indicators included in the analysis be able to quantify a country's level of well-being. One of the approaches identified following the analysis of the literature proposes the use of the Gross Domestic Product (GDP) for measuring the economic level of a country (Remeikienè et al., 2020). Thus, in order to be able to make comparisons between countries, in the case of the construction of the Social Inclusion Index for EU countries, we considered it useful to include the Real GDP growth rate per capita but also an indicator to identify the amounts allocated by each country for social protection (Percentage of GDP spent on social protection).

On the other hand, there are definitions addressing social inclusion as a state: “... a society in which all people have the opportunity to participate fully in political, cultural, civic and 
economic life because they feel appreciated, their differences of opinion are respected and their basic needs are met so that they can live in dignity".

Shookner (2002, pp. 2-3) highlighted five fundamental values that would lead to actions meant to improve social inclusion: social justice, diversity assessment, opportunities for choice, rights and services, and collaboration. Participation in social activities other than purely economic is generally considered as an indicator of social inclusion (Burchardt et al., 1999). There are experts who have argued that the degree of economic inclusion is important for understanding the level of social inclusion (Aasland \& Fløtten, 2001; Rawal, 2008). Similarly, the efforts made during the 1970s and 1980s to quantify the number of social contacts or connections were associated with results such as physical and mental health measurements (Felea et al., 2013).

The importance of social indicators for European policy making was also noted by Atkinson et al. (2002). He emphasized the importance of social indicators for assessing the level of social development of a nation and, in particular, for assessing the impact of social and economic integration policies created with them. Aggregated indicators do not only analyse unique issues, such as poverty, but allow analysis of the concept of social inclusion / exclusion of a multidimensional phenomenon, the result being useful in the elaboration of European policies. However, the inclusion of environmental, social and governance dimensions helps decision makers to identify policies that can lead to programs and strategies that promote diversity and social inclusion of employees (Suciu et al., 2020). At the same time, at the macroeconomic level, public policies are needed for migrant workers, by returning them to their country of origin with the possibility of being employed with a remuneration that would give them the possibility of a decent living (Vasile et al., 2020).

Inspired by The AQ Social Inclusion Index (Americas Quarterly, n.d.), calculated for the first time in 2012, a similar indicator for EU member countries is required for the multidimensional characterization of social inclusion. The data sources used by the Americas Quarterly do not include values for European countries, and a particular emphasis is placed on race and ethnic inequalities, phenomena not truly prevalent in the European area, where, however, there are a number of other peculiarities.

Each country of the 28 is being evaluated against the others for each indicator of the 12 used, whether it is an exit or entry indicator, with a score of 1 to 28 . The totals then turn to a scale from 0 to 100 .

Social inclusion implies more than improving access to economic resources, this being the process of improving the conditions for participation in society, especially for disadvantaged people, by enhancing opportunities, respecting rights of all kinds, access to resources and free expression. At the same time, it is an essential aspiration for Agenda 2030.

In fact, "social inclusion is the political response to exclusion ... it is about supportive and transformation". For Jenson (2007) this political response is to ensure full access for all people to human fundamental rights, which is considered a strategy that is more successful when such rights are included in the laws of a country (Schrecker et al., 2010). In this context, the inclusion of the Corruption Perceptions Index (CPI) in the calculation of the Social Inclusion Index (SII) for EU countries only serves to highlight the link between corruption and inequality, as levels of corruption perception are correlated with those of economic and social 
development. In many countries, people are deprived of basic needs, which is also reflected in the CPI (Transparency International, 2016) results which indicate high levels of perceived corruption in emerging countries, practically measuring the perceived level of corruption rather than the actual level of corruption (Budsaratragoon \& Jitmaneeroj, 2020).

\section{The European context}

In Laeken December 2001, the European Council adopted a set of socially defined and mutually agreed social indicators, which should play a central role in monitoring the performance of the Member States and in promoting social inclusion. The purpose of these indicators is to allow EU Member States and the European Commission to monitor progress at national and European level in relation to the main objectives in the field of social inclusion. At the same time, they can prove useful in areas with more political action and needed to exchange good practice on social inclusion policies.

Building a social inclusion indicator system is an important step forward in the development of the EU social policy and has the potential to outline the framework where Member States develop national policies to combat poverty and social exclusion.

Obviously, some multidimensional measures work, rather at a zonal / regional level. At national level, indicator systems are relatively simple to use. These, monitored and calculated annually, are easy to integrate into national methodologies. The indicators combine national information on specific challenges with the transnational key objectives agreed by the Heads of State and Government of the EU.

This issue was also debated in the convention Davos 2018, organized by the World Economic Forum (WEF), by analyzing the Inclusive Development Index (IDI) that measures the economic performance of 103 countries, on namely how they perform in the 11 dimensions of economic progress beyond GDP (World Economic Forum, 2018a, 2018b). It has 3 pillars: growth and development; inclusion and inter-regional equity. Between emerging countries Romania ranks (2018) in 10th place, with a score of 4.43, slightly increasing over the last 5 years.

Composite indicators are used for a variety of purposes. In the context of this paper, have been selected specific indicators of the youth exclusion analysis. In this regard, the Committee's recommendations have been taken into account to focus on common indicators addressing social outcomes, rather than the means by which they are achieved (e.g. level of education reached, total school expenditure). And, last but not least, the set of indicators was as transparent and accessible as possible.

\section{Construction of the Social Inclusion Indicator for the European Union countries}

\subsection{Composite indicators}

Composite indicators are used to analyze the evolution of societies from different perspectives such as industrial competitiveness, social progress, sustainable development, globalization and innovation, being relevant in policy making. Thus, an important stage in the 
construction of the final composite indicator is given on one hand by identifying the most relevant indicators in its composition and on the other by the weight and significance of each. Improving the way these indicators are built and used is an important research issue both theoretically and operationally.

To avoid data manipulation and misrepresentation, the methodological aspects used in constructing a composite indicator should be addressed in a transparent manner. According to the OECD "Handbook on Constructing Composite Indicators" it is recommended to create a theoretical framework that can form the basis for selecting and combining individual indicators so that the final composite indicator represents a significant measure to achieve the proposed goal (Nardo et al., 2005). Obviously, it is a challenge for theoreticians and analysts to select data so that individual indicators are relevant to the phenomenon under consideration, to have a high degree of coverage of the country, but also the imputation of missing data and the analysis of extreme values. An important step in building a composite indicator is the multivariate analysis for the research of the general structure of the indicators, the evaluation of the data set and the explanation of the methodological choices. An essential stage in ensuring the comparability of indicators that characterize different plans with different content and different measures is the normalization of indicators. Particular attention must be paid to extreme values as they can influence subsequent steps in the process of building a composite indicator.

In order to meet the ultimate goal of multicriteria characterization, it is performed a weighing and aggregating of the indicators included in the composite indicator to correct correlation and compensation problems between them, as well as performing analyzes to assess the robustness of the composite index.

Transparency is a feature of composite indicators to be broken down into their core indicators or values to identify links with other variables, correlating the composite indicator with other existing indicators.

Last but not least, specialists recognize that the presentation and visualization of composite indicators can be achieved in different ways, which can influence their interpretation, and often important aspects are hidden by globalization.

\subsection{Social Inclusion Index for EU Member States}

The indicators included in the Social Inclusion Index are presented in Appendix 1 through a brief description, the index architecture being influenced by the selection criteria according to the sources of each, sources found in different databases. In some cases, there is a compromise between the quality and precision of a social indicator and its geographical coverage. For Factorial Analysis based on the principal components to be considered viable, each of the indicators used to calculate the index must be relatively free from the measurement error (Dunteman, 1989).

For each variable in the ISI (Mihai, 2017), a ranking was built, with each country receiving a score of 1 to 28 (depending on the values of each indicator) being positioned in relation to other countries. For a better accuracy of results, a "first-ranked" country-wide approach was used for the $\operatorname{In} 4, \operatorname{In} 5, \operatorname{In} 6, \operatorname{In} 7, \operatorname{In} 8$ indicators to calculate the final score. Thus, the coun- 
try ranked first in the ranking is used as a reference (100\%) and the other countries receive points proportionally. Practically, this method does not change the ranking of individual indicators, but may affect the final ranking. Instead of artificially establishing a 1-point difference between countries, this method uses the actual variation of scores to assign the points that count to the final score because it respects the difference sizes by providing points on the indicator in a "more equitable" manner.

Figure 1 presents a performance score for each country of the European Union showing the value of the Social Inclusion Index (Appendix 2). IBM SPSS trials were used for data processing.

The Social Inclusion Index for EU countries aims to quantify social inclusion for each country/region as a complement to traditional measures to reduce social exclusion.

At the same time, measuring social inclusion can help to adjust EU social agenda strategies.

When selecting unique indicators that were used in IIS construction for EU countries, account was taken of the particularities of Member States in their national policies to reduce social exclusion. Strategies targeting the promotion of social inclusion use individual indicators that cannot always provide an assessment of social inclusion globally.

Social inclusion is the capacity of a citizen to participate in the political, economic and social life of his society, which includes, besides the economic side, access to basic social services, access to the official labour market, access to infrastructure - and institutional, civil and political participation and lack of discrimination (race, ethnicity or gender).

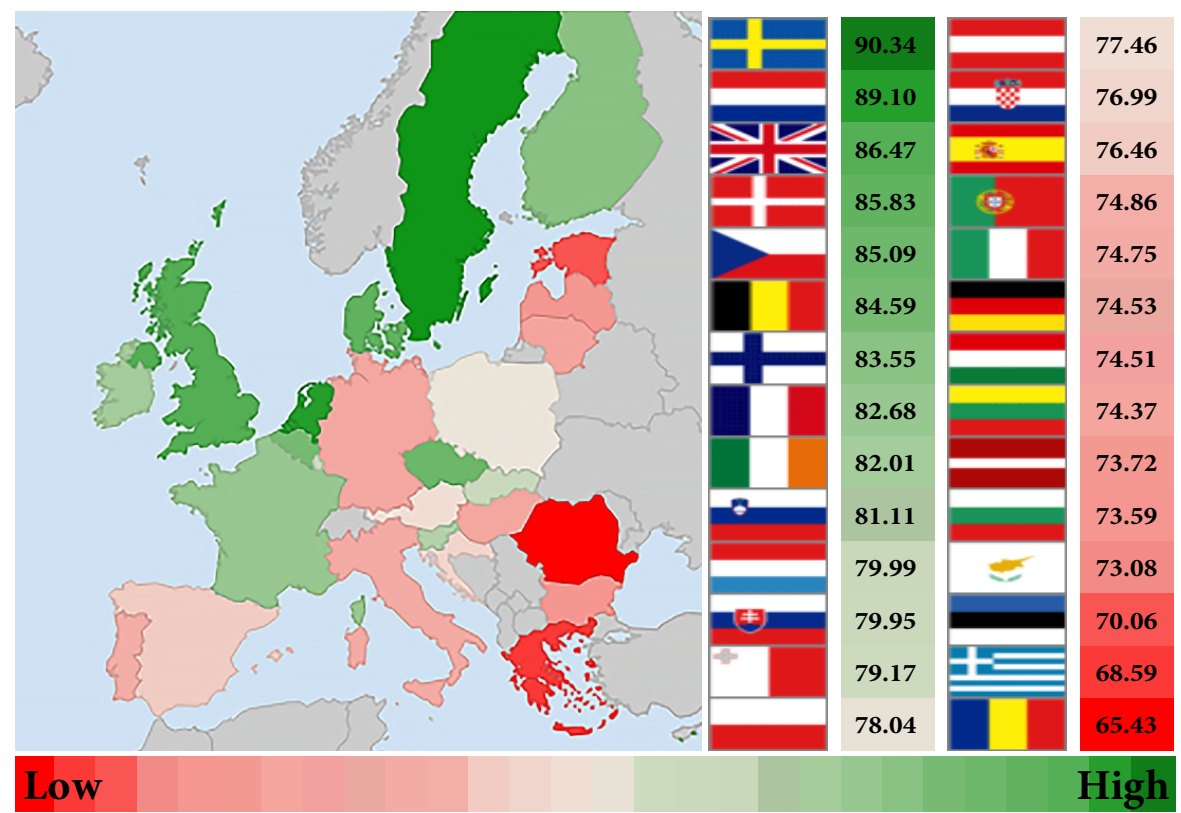

Figure 1. Representation of the Social Inclusion Index 


\section{Methods of multivariate data analysis applied to the Social Inclusion Index}

The fundamental nature of the data needs to be carefully analyzed in order to avoid building a composite indicator to mislead decision-makers and the general public, thus leading to the creation of unnecessary or incorrect policies.

Techniques and methods of multivariate data analysis are used to study the overall structure of the set of individual indicators, to adequately assess them and, in particular, to guide subsequent methodological choices (e.g. weighting, aggregation etc.). Thus, we use appropriate data analysis methods in order to determine the consistency of the indicators included in the ISI calculation, to verify the basic data structure along at least two dimensions (individual and country indicators) and to identify groups of indicators or groups of countries that are considered from the point of view statistical view with "similar" scores.

The Cronbach alpha (c-alpha), used to verify the degree of correlation between a set of variables, studies the internal consistency of individual indices, or can be used as a method to reduce some of these.

Principal Component Analysis (PCA) is used to explore whether statistically the dimensions of the phenomenon are well balanced in the composite indicator. Otherwise, a review of individual indicators may be necessary. PCA shows how different variables change in relation to one another and how they are associated, by transforming the correlated variables into a new set of uncorrelated variables using a covariance matrix or a correlation matrix.

Factorial Analysis (FA) is similar to PCA, but is based on a particular statistical model.

Cluster Analysis performs the classification of large amounts of information in easy to manage sets. It is often used in the development of composite indicators for grouping similar country-based information based on different individual indicators.

\subsection{Cronbach's alpha coefficient}

Cronbach's alpha coefficient (Cronbach, 1951) is a statistic that shows how well a set of measures describes a single characteristic and represents a global correlation of individual indicators in which the final result can take values between 0 and 1, although in some situations may be negative. A value close to 0 or a negative Cronbach alpha can indicate a perfectly valid test if we have reverse coding or multiple factors. A generally accepted rule is that a value of 0.7 (sometimes 0.6 ) of the coefficient indicates an acceptable reliability and a value equal to 0.8 or greater indicates good reliability. On the other hand, a value between 0.95 and 1 is not necessarily desirable because it indicates that the elements can be totally redundant. Normally, the value of Cronbach alpha tends to increase as the number of items increases, but this does not necessarily mean an increase in internal consistency.

For a test consisting of a $k$-number of indicators measuring economic, social and political aspects (for $X$ countries) the Cronbach alpha coefficient is calculated by correlating the score for each scale element with the total score for each observation then comparing it with the variance for all the individual scores of the elements included in the analysis:

$$
\alpha=\frac{k}{k-1}\left(1-\frac{\sum_{j=1}^{k} \sigma_{Y_{i}}^{2}}{\sigma_{X}^{2}}\right),
$$


where: $k$ - number of individual indicators; $X=Y_{1}+Y_{1}+\cdots+Y_{k} ; \sigma_{Y_{i}}^{2}$-variance of indicator $i ; \sigma_{X}^{2}$ - the variance associated with the total scores observed.

Standardized, Cronbach alpha is defined as:

$$
\alpha_{s}=\frac{k \cdot \bar{r}}{1+(k-1) \cdot \bar{r}}
$$

where: $k$ - the number of individual indicators; $\bar{r}$ - the average correlation between the indicators.

The coefficient $\alpha=0.762$ (Table 1 ) indicates a high internal consistency of the indicators included in the composite indicator calculation.

As shown in the last column of Table 2, removing an indicator from the individual may result in an improvement in the Cronbach alpha coefficient, this column showing if the value of $\alpha$ was removed. Removing Indicators In1, In 6 or In 12 would result in a higher result than the one originally obtained. Removing these indicators would lead to a slight improvement of a. At the same time, for these elements, we see negative values in the "Corrected item-total correlation" column, which can help us decide whether or not to remove this item.

Cronbach alpha represents a global reliability factor for a set of variables, but if the variables studied are ordinal or categorical and reflect personal qualities or other dimensions, they will not be able to distinguish between them.

If a high value of $\alpha$ points out that individual indices have a one-dimensional component, a low value can suggest that items are grouped into two or more dimensions, as they are

Table 1. SPSS ${ }^{\circledR}$, Reliability Statistics

\begin{tabular}{|c|c|c|}
\hline Cronbach's alpha & Cronbach's alpha based on standardized items & N of items \\
\hline 0.762 & 0.762 & 12 \\
\hline
\end{tabular}

Table 2. SPSS ${ }^{\circledR}$, Item Statistics and Item-Total Statistics

\begin{tabular}{|c|c|c|c||c|c|c|c|c|c|}
\hline Item & Mean & $\begin{array}{c}\text { Std. } \\
\text { Dev. }\end{array}$ & N & Item & $\begin{array}{c}\text { Scale mean } \\
\text { if item } \\
\text { deleted }\end{array}$ & $\begin{array}{c}\text { Scale } \\
\text { variance if } \\
\text { item deleted }\end{array}$ & $\begin{array}{c}\text { Corrected } \\
\text { item-total } \\
\text { correlation }\end{array}$ & $\begin{array}{c}\text { Squared } \\
\text { multiple } \\
\text { correlation }\end{array}$ & $\begin{array}{c}\text { Cronbach's } \\
\text { alpha if } \\
\text { item deleted }\end{array}$ \\
\hline In1 & 14.67 & 8.334 & 27 & In1 & 155.41 & 2959.635 & -0.313 & 0.821 & 0.818 \\
\hline In2 & 14.67 & 8.321 & 27 & In2 & 155.41 & 2236.020 & 0.559 & 0.892 & 0.727 \\
\hline In3 & 14.93 & 8.062 & 27 & In3 & 155.15 & 2267.054 & 0.538 & 0.642 & 0.730 \\
\hline In4 & 13.04 & 8.698 & 27 & In4 & 157.04 & 2006.114 & 0.852 & 0.862 & 0.688 \\
\hline In5 & 14.00 & 8.143 & 27 & In5 & 156.07 & 2169.379 & 0.672 & 0.721 & 0.714 \\
\hline In6 & 13.85 & 8.484 & 27 & In6 & 156.22 & 2929.333 & -0.279 & 0.319 & 0.816 \\
\hline In7 & 12.78 & 8.568 & 27 & In7 & 157.30 & 2235.293 & 0.539 & 0.439 & 0.729 \\
\hline In8 & 14.89 & 8.126 & 27 & In8 & 155.19 & 2099.080 & 0.779 & 0.859 & 0.701 \\
\hline In9 & 14.41 & 8.418 & 27 & In9 & 155.67 & 2259.000 & 0.519 & 0.534 & 0.731 \\
\hline In10 & 14.63 & 8.077 & 27 & In10 & 155.44 & 2106.333 & 0.774 & 0.937 & 0.702 \\
\hline In11 & 13.26 & 8.461 & 27 & In11 & 156.81 & 2267.157 & 0.505 & 0.751 & 0.733 \\
\hline In12 & 14.96 & 7.944 & 27 & In12 & 155.11 & 2745.718 & -0.076 & 0.412 & 0.794 \\
\hline
\end{tabular}


multidimensional. In such situations, the internal consistency coefficient calculated on all variables will have a small value, but calculated on groups of variables, will have a high value.

In order to identify the groups of indicators, factorial analysis is applied, which will indicate to what extent they tend to group and which are the elements of each dimension. Subsequently, if the grouping of the individual indicators is accepted according to the results of the factorial analysis, their reliability is verified by the coefficient $\alpha$ for each group separately.

\subsection{Factor Analysis and Analysis of Principal Components}

Factor Analysis is probably the most widely used multivariate technology, but there are also specialists who consider it an useless procedure that can be used to support almost any desired interpretation of the data. Used correctly, factor analysis can provide useful information being utilized to explore data for models in order to confirm our assumptions or to reduce numerous variables to a more manageable number.

In the literature, PCA has often been approached as a special case of FA, which is reflected in IT packages that integrate the PCA as an option in a factor analysis program. This is not quite right if we think that both PCA and FA - although aimed at reducing the dimensionality of a dataset - use quite distinct techniques. The starting point of this confusion goes from Hotelling (1933), which introduced the principal components in the context of providing a small number of "more fundamental" variables, determines the values of the initial variables, and Reyment and Jvreskog (1996), Benzécri (1992) used the term to include a broad spectrum of multivariate methods.

We use FA if we want a model that explains the correlations between the data and we use PCA when we need to approximate the data in a space of a smaller size. In this paper we look at the Principal Component Analysis as a Factor Analysis technique, meaning we will consider total data dispersion. PCA consists in highlighting the change of variables relative to others and how they are associated: transformation of correlated variables into a new set of uncorrelated variables using the covariance matrix or its standardized form (correlation matrix). Because individual indicators that have similar values in all countries are not of interest (cannot explain different performance), the highest load factor is attributed to individual indicators with the highest variation in values between countries.

At the same time, the purpose of using PCA and FA was to highlight the fundamental difference between the two: Principal Component Analysis is a linear combination of variables and Factorial Analysis a model for measuring a latent variable.

In the current paper, starting from the analysis of the correlations observed between the variables describing the phenomenon of social inclusion, the use of the Factorial Analysis helps us to identify the structure of these data, indicating the existence of a small number of dimensions. Variables that are comprised of the same factor (latent dimension) will be strongly correlated with each other and slightly correlated with the other variables (Culic, 2004; Rotariu et al., 2006).

The objective is to explain the data variance observed by some linear combinations of the original data. Even though there are $\mathrm{n}$ variables (in the calculation of the indicator in this paper $n=12), x_{1}, x_{2}, \ldots, x_{n}$, much of the data variation can often be embedded in a 
small number of variables - principal components or linear relationships of the original data, which are not correlated.

We consider the general model of Factorial Analysis (Figure 2), with $n$ observed variables (individual indices) and $k$ orthogonal common factors.

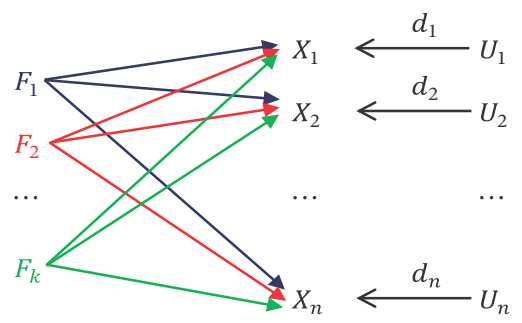

Figure 2. Model factor analysis

Factorial matrix:

\begin{tabular}{ccccc} 
& $F_{1}$ & $F$ & $\ldots$ & $F_{k}$ \\
\hline$X_{1}$ & $a_{11}$ & $a_{12}$ & $\ldots$ & $a_{1 k}$ \\
$X_{2}$ & $a_{21}$ & $a_{22}$ & $\ldots$ & $a_{2 k}$ \\
$\ldots$ & & & & \\
$X_{n}$ & $a_{n 1}$ & $a_{n 2}$ & $\ldots$ & $a_{n k}$
\end{tabular}.

Algebraic form of equations:

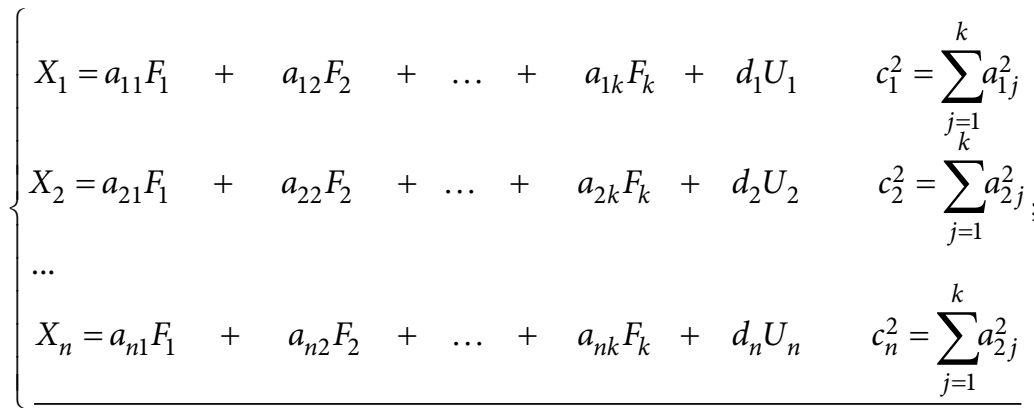

$$
\begin{aligned}
& \lambda_{1}^{2}=\sum_{i=1}^{n} a_{i 1}^{2}, \quad \lambda_{2}^{2}=\sum_{i=1}^{n} a_{i 2}^{2}, \quad \lambda_{k}^{2}=\sum_{i=1}^{n} a_{i k}^{2},
\end{aligned}
$$

where: $X_{i}$ - common orthogonal factors, $i=\overline{1, n} ; F_{j}$ - common orthogonal factors, $j=\overline{1, k}$; $U_{i}$ - the factors of uniqueness; $a_{i j}$ - the factorial saturations for each observed variable. They are the regression coefficients in which latent variables are independent variables, and the variables observed are dependent variables. They are found in the matrix pattern (factor) table. We interpret the factors according to the correlations between the factors and the variables observed. They are reported in the matrix structure table. Structure matrix coincides with the pattern matrix if the rotation is orthogonal and differs from it if the rotation is oblique. $c_{i}^{2}$ - communalities (the common variance of the variable $X_{i}$ ); $\lambda_{i}^{2}$ - own values (the variance synthesized by a factor); $\lambda_{1}^{2}>\lambda_{2}^{2}>\cdots>\lambda_{k}^{2}$. 
In the case of the Social Inclusion Indicator, we want to check the existence of latent factors that can explain the common variance of the observed set of variables. To determine a typology of individual indicators and latent factors that determine it, we will use Factorial Analysis applying the PCA method of factor extraction and, assuming the factors are independent, the Varimax orthogonal method of rotation of factors.

The correlation matrix of the 12 standardized variables (Appendix 3) indicates the existence of some strongly correlated subsets of variables (the PCA requires some correlations between the variables included in the analysis to be greater than 0.30).

To analyze whether the test is statistically significant, we calculate the appropriateness of Kaiser-Meyer-Olkin sampling. KMO is a statistic for comparing magnitudes of correlation coefficients observed with the magnitude of partial correlation coefficients. KMO's global statistics are calculated as a sum of KMO statistics for each individual indicator and range from 0 to 1 . If a KMO value is less than 0.60 , it is recommended to drop the individual pointers with the lowest values individual KMO statistics, continue the process until the KMO's overall value is greater than 0.60 .

$$
K M O=\frac{\sum_{i} \sum_{i \neq j} r_{X_{i} X_{j}}^{2}}{\sum_{i} \sum_{i \neq j} r_{X_{i} X_{j}}^{2}+\sum_{i} \sum_{i \neq j} b_{X_{i} X_{j}}^{2}},
$$

where: $r_{X_{i} X_{j}}$ - the correlation coefficient between $X_{i}$ and $X_{j} ; b_{X_{i} X_{j}}$ - the partial correlation coefficient between $X_{i}$ and $X_{j}$ when all the other variables are controlled.

The values 0.681 for the KMO index and 183.289 for the Bartlett Sphericity test (Sig. = 0.000 ) indicate that there is a strong relationship between the variables, we can basically reject the hypothesis that the variables are uncorrelated (Table 3). At the same time, these values confirm the presence of one or more common factors that motivate the application of a factor extraction procedure using the PCA method.

The table that includes the common variant (communality) shows us a good representation of the variables by the factorial model, and from the one that shows the total variance explained, we observe four factors fulfilling the selection criterion (own values $\lambda_{i}^{2} \geq 1$ ). In the context of the initial factorial solution, not rooted, the factors explain $78.743 \%$ of the variance of the analyzed values, and the $21.257 \%$ difference remains unexplained by this factorial model.

After factor rotation, we notice a redistribution of the variance explained by each factor, even if the first factor best explains the variance of the included variables with the highest value, it loses the degree of saturation in favor of the other three factors. Basically, the saturation value for each factor changes as the value of the total variation remains unchanged.

An important role in the analysis is held by the Component Matrix, but the more useful structure for interpretation remains, however, the one obtained by turning factors, especially if we consider that it provides a better "vision".

Table 3. SPSS ${ }^{\circledR}$, Item Statistics and Item-Total Statistics

\begin{tabular}{|l|c|c|}
\hline \multicolumn{2}{|c|}{ Kaiser-Meyer-Olkin measure of sampling adequacy } & 0.681 \\
\hline Bartlett's test of Sphericity & Approx. Chi-Square & 183.289 \\
& $\mathrm{df}$ & 66 \\
& Sig. & 0.000 \\
\hline
\end{tabular}


It is noted that the solution is obtained by a process of 10 iterations. From the total number of variables, same number of components can be extracted, as each own value represents the part of variance explained by that component.

The name of the factors is influenced by their effect on the observed variables. Certainly, factor rotation will alter their saturation on variables, which can also lead to changing their interpretation (Table 4). And in the case of the Facial Analysis applied to the Social Inclusion Indicator, we can observe that after the spinning of the factors we can identify the new obtained results.

Used as an alternative method for identifying the number of principal components included in the analysis, the graphical method (Figure 3) does nothing but confirm the results identified in total variance explained (Table 5). It is obvious that the largest contribution is made by component 1 , while components with an eigenvalue below $1\left(\lambda_{i}^{2}<1\right)$ are considered with a smaller variance than the initial one, being less important in the analysis.

Table 4. Identifying factors after factor rotation

\begin{tabular}{|c|c|c|c|}
\hline Factor & Variable & Saturation & Factor identification \\
\hline \multirow{3}{*}{1} & Political rights (In4) & 0.883 & \multirow{3}{*}{$\begin{array}{l}\text { The political context } \\
\text { (Trust in Public Institutions } \\
\text { and Government } \\
\text { Organizations) }\end{array}$} \\
\hline & Civil liberties (In5) & 0.870 & \\
\hline & Perceptions of Corruption Index (In10) & 0.860 & \\
\hline \multirow[b]{2}{*}{2} & GDP growth rate (average 2006-2016) (In1) & -0.890 & \multirow[b]{2}{*}{ The socio-economic context } \\
\hline & $\begin{array}{l}\text { Percentage of GDP spent on social protection } \\
\text { (In2) }\end{array}$ & 0.814 & \\
\hline 3 & Women's rights (In6) & 0.824 & Women's rights \\
\hline 4 & $\begin{array}{l}\text { Employment rate of the population aged } \\
15-64(\operatorname{In} 12)\end{array}$ & 0.923 & Employment \\
\hline
\end{tabular}

Table 5. SPSS ${ }^{\circledR}$, Common variance and total variance explained

\begin{tabular}{|l|l|l|}
\hline \multicolumn{3}{|c|}{ Communalities } \\
\hline & Initial & Extraction \\
\hline Zscore: In1 & 1.000 & 0.840 \\
Zscore: In2 & 1.000 & 0.842 \\
Zscore: In3 & 1.000 & 0.581 \\
Zscore: In4 & 1.000 & 0.807 \\
Zscore: In5 & 1.000 & 0.823 \\
Zscore: In6 & 1.000 & 0.766 \\
Zscore: In7 & 1.000 & 0.682 \\
Zscore: In8 & 1.000 & 0.821 \\
Zscore: In9 & 1.000 & 0.745 \\
Zscore: In10 & 1.000 & 0.875 \\
Zscore: In11 & 1.000 & 0.804 \\
Zscore: In12 & 1.000 & 0.863 \\
\hline & \\
\hline Extraction Method: \\
Principal Component Analysis. \\
\hline
\end{tabular}

\begin{tabular}{|c|c|c|c|c|c|c|c|c|c|}
\hline \multicolumn{10}{|c|}{ Total Variance Explained } \\
\hline \multirow{2}{*}{ 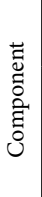 } & \multicolumn{3}{|c|}{ Initial Eigenvalues } & \multicolumn{3}{|c|}{$\begin{array}{l}\text { Extraction Sums of } \\
\text { Squared Loadings }\end{array}$} & \multicolumn{3}{|c|}{$\begin{array}{l}\text { Rotation Sums of Squared } \\
\text { Loadings }\end{array}$} \\
\hline & 즁 & 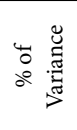 & 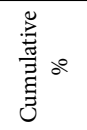 & $\stackrel{\pi}{0}$ & 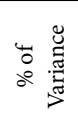 & 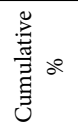 & 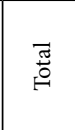 & \% & 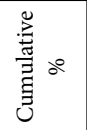 \\
\hline 1 & 5.117 & 42.640 & 42.640 & 5.117 & 42.640 & 42.640 & 3.971 & 33.092 & 33.092 \\
\hline 2 & 1.898 & 15.815 & 58.455 & 1.898 & 15.815 & 58.455 & 2.377 & 19.807 & 52.899 \\
\hline 3 & 1.283 & 10.690 & 69.145 & 1.283 & 10.690 & 69.145 & 1.864 & 15.532 & 68.430 \\
\hline 4 & 1.152 & 9.598 & 78.743 & 1.152 & 9.598 & 78.743 & 1.237 & 10.312 & 78.743 \\
\hline 5 & 0.621 & 5.176 & 83.919 & & & & & & \\
\hline 6 & 0.570 & 4.749 & 88.668 & & & & & & \\
\hline 7 & 0.494 & 4.113 & 92.781 & & & & & & \\
\hline 8 & 0.335 & 2.791 & 95.572 & & & & & & \\
\hline 9 & 0.205 & 1.709 & 97.281 & & & & & & \\
\hline 10 & 0.144 & 1.203 & 98.484 & & & & & & \\
\hline 11 & 0.127 & 1.058 & 99.542 & & & & & & \\
\hline 12 & 0.055 & 0.458 & 100.000 & & & & & & \\
\hline
\end{tabular}


Table 6. SPSS ${ }^{\circledR}$, Matrix of components and component matrix after rotation

\begin{tabular}{|c|c|c|c|c|}
\hline \multicolumn{5}{|c|}{ Component Matrix ${ }^{\mathrm{a}}$} \\
\hline & \multicolumn{4}{|c|}{ Component } \\
\hline & 1 & 2 & 3 & 4 \\
\hline Zscore: In 1 & \multirow{7}{*}{0.813} & & & \\
\hline Zscore: $\operatorname{In} 2$ & & & & \\
\hline Zscore: In 3 & & & & \\
\hline Zscore: $\operatorname{In} 4$ & & & & \\
\hline Zscore: In5 & & & & \\
\hline Zscore: In6 & & & & \\
\hline Zscore: In7 & & & & \\
\hline Zscore: In8 & \multirow[t]{2}{*}{0.903} & & & \\
\hline Zscore: In9 & & & & \\
\hline Zscore: In10 & \multirow[t]{3}{*}{0.853} & & & \\
\hline Zscore: In11 & & & & \\
\hline Zscore: $\operatorname{In} 12$ & & & & \\
\hline
\end{tabular}

\begin{tabular}{|l|c|c|c|c|}
\hline \multicolumn{5}{|c|}{ Rotated Component Matrix ${ }^{\mathbf{a}}$} \\
\hline & \multicolumn{3}{|c|}{ Component } \\
\cline { 2 - 5 } & 1 & 2 & 3 & 4 \\
\hline Zscore: In1 & & -0.890 & & \\
Zscore: In2 & & 0.814 & & \\
Zscore: In3 & & & & \\
Zscore: In4 & 0.883 & & & \\
Zscore: In5 & 0.870 & & 0.824 & \\
Zscore: In6 & & & & \\
Zscore: In7 & & & & \\
Zscore: In8 & & & \\
Zscore: In9 & & & \\
Zscore: In10 & 0.860 & & \\
Zscore: In11 & \multicolumn{5}{|c|}{} \\
Zscore: In12 & \multicolumn{5}{|c|}{} \\
\hline Extraction Method: Principal Component Analysis; \\
Rotation Method: Varimax with Kaiser Normalization; \\
a - Rotation converged in 10 iterations.
\end{tabular}

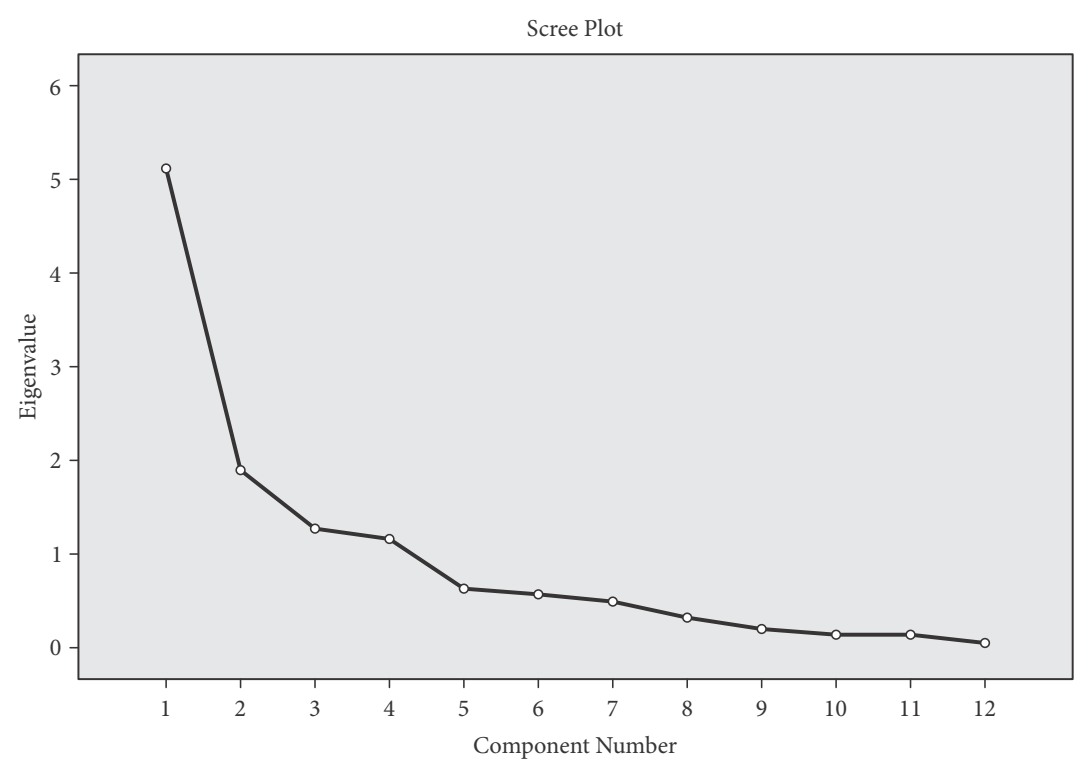

Figure 3. SPSS ${ }^{\circledR}$, Factorial Analysis, graphical representation of the 12 variables

From the results displayed in Component Transformation Matrix, we note two significant correlations: Factor 2 - Factor 3 and Factor 3 - Factor 4 (Figure 4). Simultaneously, the graphical representation for the rotation of the factors, in the three-dimensional space, indicates the representativeness of a variable in the analysis comparing the distance between them and the origin of each subspace generated by the three dimensions. The greater this distance, the more relevant we can give to the variable included in the analysis (for example ZIn12), which is obviously correlated with the results obtained in the Rotated Component Matrix (Table 6, Figure 4). 


\begin{tabular}{|c|c|c|c|c|}
\hline \multicolumn{5}{|c|}{ Component Transformation Matrix } \\
\hline 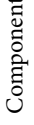 & 1 & 2 & 3 & 4 \\
\hline 1 & 0.838 & 0.462 & -0.287 & 0.032 \\
\hline 2 & -0.141 & 0.697 & 0.701 & -0.060 \\
\hline 3 & 0.358 & -0.366 & 0.369 & -0.776 \\
\hline 4 & 0.386 & -0.410 & 0.539 & 0.627 \\
\hline \multicolumn{5}{|c|}{$\begin{array}{l}\text { Extraction Method: } \\
\text { Principal Component Analysis; } \\
\text { Rotation Method: } \\
\text { Varimax with Kaiser Normalization. }\end{array}$} \\
\hline
\end{tabular}

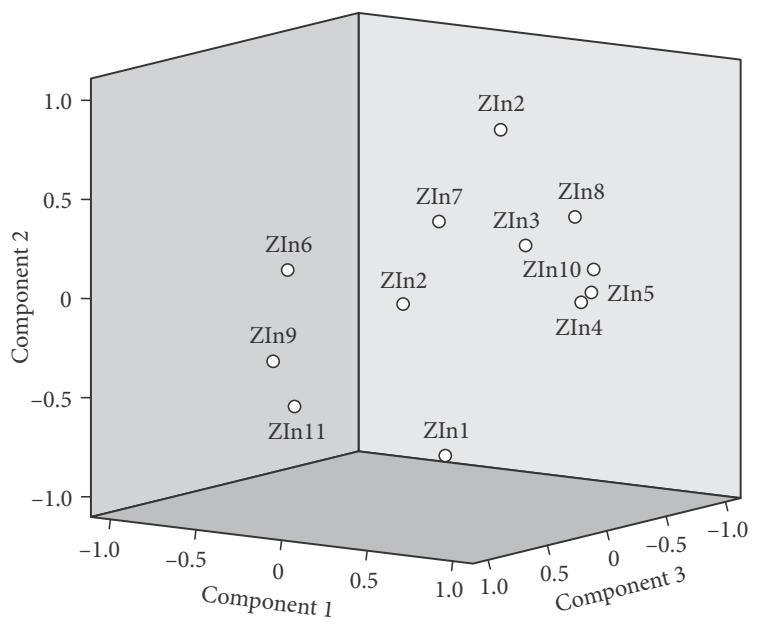

Figure 4. SPSS ${ }^{\circledR}$, Component Transformation Matrix

Following the results, we can build an index that reflects Factor 1. It can be calculated with:

- simple additive scales - the relationship between factors and variables is not taken into account (it can also be done with the help of dichotomizing the variables);

- factorial scores - with additive scales that take into account the intensity of the relationships between factors and variables. Weights are given to different variables. The observed variables may signal stronger or more modest latent dimension (factor) so that it can get different weights in the construction of the final index. The weight represents a score by which we multiply the value of the respective variable for each case. Score is provided by Factorial Analysis and appears as a new variable in the database.

In order for the size reduction to be meaningful, is necessary to have sufficiently large correlations between the variables, otherwise they will be excluded from the analysis. The same applies for very high correlations to avoid extreme singularity, perfectly correlated variables. The steps listed above are resumed, after deleting the variables that do not contribute to multicollinearity. After processing the data, we will obtain a number of factors at most equal to the ones obtained in the previous situation.

\subsection{Social Inclusion Index for EU Member States}

Sweden can be considered a model for social inclusion among EU Member States. The position at the top of the ranking is due to the strong performance of factors, from growth and job creation, to the protection of political and civil rights.

It is worth mentioning that a Joint Declaration (Regeringskansliet, 2015) was signed between Sweden and Romania, the countries that ranked first and last in the Social Inclusion Index of the European Union countries, in order to strengthen the cooperation in the field of social policies in the two countries (June 5, 2015). In this context, in 2017, the Swedish 
State Secretary (Ms Pernilla Baralt) underlined: "In the current European situation, especially as our governments are animated by common interests, we should agree on a wider dialogue framework; to express our positions at other international meetings or forums, on an agenda of problems and correlated solutions, through packages of programs addressed to the subjects that condition social inclusion" (Fonduri Europene Structurale si de Investiții, 2017).

If we take into account the four factors determined on the basis of PCA and FA and the ranking obtained from the calculation of the Social Inclusion Index (Table 7), we note:

Table 7. SPSS ${ }^{\circ}$, Sweden versus Romania

\begin{tabular}{|l|l|c|c|}
\hline \multicolumn{1}{|c|}{ Factor } & \multicolumn{1}{|c|}{ Variable } & Sweden & Romania \\
\hline \multirow{3}{*}{ 1. Political context } & Political rights (In4) & 1 & 25 \\
\cline { 2 - 4 } & Civil liberties (In5) & 1 & 25 \\
\cline { 2 - 4 } & Perceptions of Corruption Index (In10) & 3 & 24 \\
\hline \multirow{2}{*}{$\begin{array}{l}\text { 2. The socio-economic } \\
\text { context }\end{array}$} & GDP growth rate (average 2006-2016) (In1) & 10 & 5 \\
\cline { 2 - 4 } & Percentage of GDP spent on social protection (In2) & 8 & 28 \\
\hline 3. Women's rights & Women's rights (In6) & 9 & 2 \\
\hline 4. Employment & $\begin{array}{l}\text { Employment rate of the population aged 15-64 } \\
\text { (In12) }\end{array}$ & 1 & 24 \\
\hline
\end{tabular}

GDP is an indicator that helps in determining the standard of living of a country, but let us not forget that it cannot refer to: health and education levels, environmental quality, out-of-work activities, income inequality, actual time work, etc. And its value does not reflect all the elements of a concept as vast as living standards. The fact that Romania's GDP per capita is higher than the GDP per capita of Sweden does not prove that the living standard in Romania is higher. A high level of GDP should not be the sole objective of governmental social inclusion policies.

\section{Conclusions}

This article highlights the usefulness of applying multivariate analysis methods with the ultimate goal of identifying factors that significantly influence the phenomenon of social inclusion in the current context of economic development.

Policies can be initiated to bring a high level of social inclusion based on identifying, analyzing and improving the factors that are directly responsible for the level of exclusion.

The results of the analysis of the phenomenon of social inclusion in the EU Member States, using the composite indicator presented in this study, confirm the high performance in adopting social inclusion policies in the Nordic countries and, at the same time, there is a slight upward trend in progress and cohesion for the states that later joined the EU (Rogge \& Konttinen, 2018; Rogge \& Self, 2019).

Although the indicator was built from the Social Inclusion Index created by Americas Quarterly (AQ), it is easy to see that it adapts to the needs of EU countries. All traditional indicators included in the index calculation cover issues that present significant variations 
in EU Member States and have taken into account radical differences between EU regions (especially between rural and urban areas), mainly in terms of accessibility of housing, personal safety or access to quality education. EU Cohesion Policies focus on less developed regions and support regional strategies to promote economic, social and territorial cohesion.

The Social Inclusion Index for EU countries is a composite index that includes indicators derived from different sources with different, error margins and a complex aggregation structure that can help build economic and inclusive development strategies.

To remedy this and to eliminate one of the limitations of this study, in subsequent analyzes will we try restructuring the individual indicators included in the analysis so that the composite indicator used to identify the level of social inclusion can also be used regionally, for each EU member state. One way to develop the social inclusion index for EU countries and to analyze social disparities, including at the regional level, would be to include in its construction specific indicators for labor market and migration analysis. The gap of socio-economic development at the level of regions can be alleviated through the process of digitization both through educational programs for developing digital skills of citizens and through the digitization of companies (Negrea et al., 2019). These elements substantiate the need to include indicators that measure the digitization component, in the construction of a new composite index of social inclusion for EU countries.

Also, the identification of good practices in the countries with the highest score of the Social Inclusion Index, Sweden and the Netherlands, can lead to solutions that can be applied in building policies and strategies to eliminate social inequalities, especially in former communist countries.

The effectiveness of using Social Inclusion Index for EU as a tool to support social inclusion strategies at national or European level also stems from the possibility of integrating it into prioritizing economic, social or policy aspects of cohesion policies.

The analysis of a Social Inclusion Index across Europe can provide answers to many recent questions, such as the WEF Davos, on how to boost economic growth but also equality and equity. After a severe economic and financial crisis, European and world decision makers and leaders are looking for new growth models and new approaches to reforms. Building a future of sustainable progress requires efforts to develop sustainable and inclusive competitive economies.

\section{Author contributions}

All authors designed the research and analysed the data. All authors wrote the paper, read, and approved the final manuscript.

\section{References}

Aasland, A., \& Fløtten, T. (2001). Ethnicity and social exclusion in Estonia and Latvia. Europe-Asia Studies, 53(7), 1023-1049. https://doi.org/10.1080/09668130120085029

Atkinson, T., Cantillon, B., Marlier, E., \& Nolan, B. (2002). Social indicators: The EU and social inclusion. Oxford University Press. https://doi.org/10.1093/0199253498.001.0001 
Americas Quarterly. (n.d.). AQ's 2012 Social Inclusion Index: Data sources and methodology. Retrieved July 18, 2020, from https://www.americasquarterly.org/aqs-2012-social-inclusion-index-data-sources-and-methodology/

Benzécri, J.-P. (1992). Correspondence analysis handbook. Marcel Dekker. https://doi.org/10.1201/9780585363035

Botha, I., Botezatu, M. A., \& Coancă, M. (2020). Innovative calculation model for evaluating regional sustainable development. Economic Computation and Economic Cybernetics Studies and Research, 54(3), 5-24. https://doi.org/10.24818/18423264/54.3.20.01

Budsaratragoon, P., \& Jitmaneeroj, B. (2020). A critique on the Corruption Perceptions Index: An interdisciplinary approach. Socio-Economic Planning Sciences, 70, 100768. https://doi.org/10.1016/j.seps.2019.100768

Burchardt, T., Le Grand, J., \& Piachaud, D. (1999). Social exclusion in Britain 1991-1995. Social Policy \& Administration, 33(3), 227-244. https://doi.org/10.1111/1467-9515.00148

Cameron, A. (2006). Geographies of welfare and exclusion: social inclusion and exception. Progress in Human Geography, 30(3), 396-404. https://doi.org/10.1191/0309132506ph614pr

Council of the European Union (Employment, Social Policy, Health and Consumer Affairs). (2004). Joint report by the Commission and the Council on social inclusion. https://ec.europa.eu/employment_social/soc-prot/soc-incl/final_joint_inclusion_report_2003_en.pdf

Cronbach, L. J. (1951). Coefficient alpha and the internal structure of tests. Psychometrika, 16(3), 297334. https://doi.org/10.1007/BF02310555

Culic, I. (2004). Metode avansate în cercetarea socială: Analiza multivariată de interdependență [Advanced methods of statistical analysis: Multivariate analysis of interdependence]. Editura Polirom (in Romanian).

Cushing, P. J., \& Roeher Institute. (2003). Policy approaches to framing social inclusion and social exclusion: An overview. Institut Roeher.

Dunteman, G. H. (1989). Principal components analysis. Sage Publications, Inc. https://doi.org/10.4135/9781412985475

Eurostat. (2017a). Expenditure on social protection \% of GDP. https://ec.europa.eu/eurostat/data brows$\mathrm{er} /$ view/tps00098/default/table?lang=en

Eurostat. (2017b). At-risk-of-poverty rate by poverty threshold, age and sex-EU-SILC and ECHP surveys. https://appsso.eurostat.ec.europa.eu/nui/show.do?dataset=ilc_li02\&lang=en

Eurostat. (2017c). Total population having neither a bath, nor a shower, nor indoor flushing toilet in their household - EU-SILC survey. https://ec.europa.eu/eurostat/databrowser/view/ilc_mdho05/default/ table?lang=en

Eurostat. (2017d). Employment and activity by sex and age - annual data (15-64 years). https://ec.europa. eu/eurostat/databrowser/view/LFSI_EMP_A_custom_780663/default/table?lang=en

Equaldex. (2018). Equaldex: the collaborative LGBT rights knowledge base. http://www.equaldex.com/

Felea, M. G., Covrig, M., Manea, D. I., \& Titan, E. (2013). Perceptions of life burdens and of the positive side of life in a group of elderly patients with diabetes: a qualitative analysis through grounded theory. Revista de cercetare si interventie sociala, 40, 7-20. http://www.rcis.ro/images/documente/ rcis40_01.pdf

Fonduri Europene Structurale si de Investiții. (2017). România și Suedia cooperează pentru incluziunea socială a grupurilor vulnerabile [Romania and Sweden cooperate for the social inclusion of vulnerable groups]. https://www.fonduri-ue.ro/arhiva-comunicate-de-presa/2188-romania-si-suediacoopereaza-pentru-incluziunea-sociala-a-grupurilor-vulnerabile (in Romanian).

Fraser, N. (2003). Redistribución, reconocimiento y exclusión social (Memorias Seminario Internacional: Inclusión social y nuevas ciudadanías, Condiciones para la convivencia y la seguridad democráticas). Alcaldía Mayor de Bogotá y Pontificia Universidad Javeriana. 
Freedom House. (2017). Freedom in the world 2017. https://freedomhouse.org/report/freedomworld/2017/scores

Freiler, C. (2002). The context for social inclusion. Laidlaw Foundation.

Grove, G. (2008). Mental capital and wellbeing: making the most of ourselves in the 21st century: state-ofscience review: factors influencing recovery from serious mental illness and enhancing participation in family, social and working life (Commissioned as part of the UK Government's Foresight Project). Government Office for Science. https://doi.org/10.1037/e600482011-001

Hotelling, H. (1933). Analysis of a complex of statistical variables into principal components. Journal of Educational Psychology, 24(6), 417-441. https://doi.org/10.1037/h0071325

Jenson, J. (2007). The European Union's citizenship regime. Creating norms and building practices. Comparative European Politics, 5(1), 53-69. https://doi.org/10.1057/palgrave.cep.6110102

Labonte, R. (2004). Social inclusion/exclusion: dancing the dialectic. Health Promotion International, 19(1), 115-121. https://doi.org/10.1093/heapro/dah112

Laeken Declaration. (2001, December 14-15). The Laeken Declaration on the Future of the European Union. In Annex 1 to the Presidency Conclusions of the European Council Meeting in Laeken (pp. 19-27). Brussels.

Mihai, M. (2017). Metode statistice aplicate in studiul fenomenelor sociale [Statistical methods applied in the study of social phenomena]. Editura ASE (in Romanian).

Mitchell, A., \& Shillington, R. (2002). Poverty, inequality and social inclusion (Working Paper Series: Perspectives on Social Inclusion). The Laidlaw Foundation.

Nardo, M., Saisana, M., Saltelli, A., Tarantola, S., Hoffman, A., \& Giovannini, E. (2005). Handbook on constructing composite indicators: Methodology and user guide (OECD Statistics Working Papers No. 2005/03). OECD Publishing.

Negrea, A., Ciobanu, G., Dobrea, C., \& Burcea, S. (2019). Priority aspects in the evolution of the digital economy for building new development policies: Acces la success. Calitatea, 20, 416-421. https://search.proquest.com/scholarly-journals/priority-aspects-evolution-digital-economy/ docview/2198414059/se-2?accountid=50247

Rawal, N. (2008). Social inclusion and exclusion: a review. Dhaulagiri Journal of Sociology and Anthropology, 2, 161-180. https://doi.org/10.3126/dsaj.v2i0.1362

Regeringskansliet. (2015, June 8). Sweden and Romania cooperate on social policy. https://www.government.se/articles/2015/06/sweden-and-romania-cooperate-on-social-policy/

Remeikienè, R., Belas, J., Kliestik, T., \& Smrcka, L. (2020). Quantitative assessment of dynamics of economic development in the countries of the European Union. Technological and Economic Development of Economy, 26(4), 933-946. https://doi.org/10.3846/tede.2020.12892

Reyment, R. A., \& Jvreskog, K. G. (1996). Applied factor analysis in the natural sciences. Cambridge University Press.

Rogge, N., \& Konttinen, E. (2018). Social inclusion in the EU since the enlargement: Progress or regress? Social Indicators Research, 135(2), 563-584. https://doi.org/10.1007/s11205-016-1504-1

Rogge, N., \& Self, R. (2019). Measuring regional social inclusion performances in the EU: Looking for unity in diversity. Journal of European Social Policy, 29(3), 325-344. https://doi.org/10.1177/0958928718792135

Rotariu, T. I., Culic, I., \& Bădescu, G. (2006). Metode statistice aplicate în ştiințele sociale [Statistical methods applied in the social sciences]. Polirom (in Romanian).

Schrecker, T., Chapman, A. R., Labonté, R., \& De Vogli, R. (2010). Advancing health equity in the global marketplace: How human rights can help. Social Science \& Medicine, 71(8), 1520-1526.

https://doi.org/10.1016/j.socscimed.2010.06.042 
Shookner, M. (2002). An Inclusion Lens: Workbook for looking at social and economic exclusion and inclusion. Population and Public Health Branch, Atlantic Region, Health Canada. https://www.allianceon.org/sites/default/files/documents/Workbook\%20for\%20looking\%20at\%20Social_and_Economic_Inclusion_Lens\%202002.pdf

Spandler, H. (2007). From social exclusion to inclusion? A critique of the inclusion imperative in mental health. Medical Sociology Online, 2(2), 3-16. https://britsoc.co.uk/files/MSo-Volume-2-Issue-2. pdf\#page $=7$

Suciu, M. C., Noja, G. G., \& Cristea, M. (2020). Diversity, social inclusion and human capital development as fundamentals of financial performance and risk mitigation. Amfiteatru Economic, 22(55), 742-757. https://doi.org/10.24818/EA/2020/55/742

Transparency International. (2016). Corruption Perceptions Index 2016. https://www.transparency.org/ news/feature/corruption_perceptions_index_2016

UNESCO Institute for Statistics. (2018). World Development Indicators. School enrollment, secondary (\% gross) (SE.SEC.ENRR). http://databank.worldbank.org/data/reports.aspx? source=2\&country $=\&$ series $=$ SE.SEC.ENRR\&period $=$

Vasile, V., Ştefan, D., Comes, C. A., Bunduchi, E., \& Ştefan, A. B. (2020). FDI or remittances for sustainable external financial inflows. theoretical delimitations and practical evidence using granger causality. Romanian Journal of Economic Forecasting, 23(4), 131-153. http://www.ipe.ro/rjef/rjef4_20/ rjef4_2020p131-153.pdf

Women, Business and the Law. (2017). Women, business and the law. Data visualization. World Bank. https://wbl.worldbank.org/en/wbl-data

The World Bank | Data. (2017). GDP growth (annual \%). World Bank national accounts data, and OECD National Accounts data files. https://data.worldbank.org/indicator/ny.gdp.mktp.kd.zg

The World Bank. (2018). Home | Global Findex. http://www.worldbank.org/en/programs/globalfindex

World Economic Forum. (2018a). The Inclusive Development Index 2018 summary and data highlights. World Economic Forum.

World Economic Forum. (2018b, January 9). Davos 2018. https://www.weforum.org/focus/davos-2018 


\section{APPENDIX}

\section{Appendix 1}

In1 - Real GDP growth per capita (2006-2016) (The World Bank | Data, 2017)

A country can only reduce poverty and inequality if there is economic growth. This variable represents the average growth rate over the period 2006-2016 using data from the World Bank. The GDP growth rate is determined by the four components of GDP: personal consumption, business investment; government spending and net trade.

\section{In2 - Percentage of GDP spent on social protection (Eurostat, 2017a)}

Expenditure on social protection is calculated in the current prices and includes: social benefits, administration costs, and other costs that consist of various social security systems.

There are no measures of the efficiency of state spending on social programs. For a calculation as close as possible to the global situation, the data series being complete for the period 2002-2012, we used the extrapolation to obtain the values for 2013.

In3 - Enrollment in high school education (UNESCO Institute for Statistics, 2018)

The indicator is the number of students enrolled in high school education regardless of age, expressed as a percentage of the corresponding school age population matching the same level of education. High-school education complements primary education at primary level and aims to lay the foundation for lifelong learning and human development, providing more discipline-specific information with the help of specialized teachers.

The data used for the countries of the European Union is taken over from the World Bank and is complete for the period 2002-2015. For countries with no data available for 2015, the calculation of values was done by extrapolation using simple methods.

A high value of this indicator generally indicates a high level of participation, but not specific if the pupils are part of the official age group or not. A large number of countries have a high rate of $100 \%$, which may mean that pupils of the same or older age outside the system are included, or that there is a high repeat rate. In this case, for a rigorous interpretation of the GER, additional information is needed to evaluate the repetition rate, those entering the system late etc.

In4 - Political rights; In5 - civil liberties (Freedom House, 2017)

Freedom in the World is an annual global report describing and analyzing political rights and civil liberties that includes numerical ratings and descriptive texts for each country and a selected group of related and disputed territories based on a methodology derived from the Universal Declaration of Human Rights, adopted by the UN General Assembly in 1948.

Based on the premise that these standards apply to all countries and territories, regardless of geographic location, ethnic/religious structure and level of economic development, the 2017 edition looks at developments in 195 countries and 14 territories between 1 January 2016 and 31 December 2016 The real world rights and freedoms enjoyed by individuals rather than governments or the performance of the government itself are assessed. Let's not forget that political rights and civil liberties can be affected by both state and non-state actors, including insurgents and other armed groups.

At the same time, Freedom House does not equate the legal guarantees of rights with these, and maintains its impartiality over territorial or separatist disputes, focusing instead 
on the level of political rights and civil liberties in a particular geographical area. Countries and territories with fewer populations are not penalized for lack of pluralism in the political system or civil society - where these limitations are sizeable and not restrictions imposed by government or other strong actors.

According to the methodology, Freedom in the World uses a three-tier classification system, composed of scores, rating and status. Thus, a country or territory can be given between 0 and 4 points for each of the 10 policy indicators and 15 indicators for assessing civil liberties; a score of 0 represents the lowest degree of freedom and a score of 4 represents the highest degree of freedom. They are structured as questions.

A maximum score of 40 points can be obtained for the political rights checklist and 60 points for civil liberties.

In6 - Women's rights (Women, Business and the Law, 2017)

These scores are the rates of maternal mortality, reproductive rights, laws that criminalize violence against women, tax provisions for child care, or women in politics. Women's rights are assessed according to "Women Business and the Law 2016" (World Bank), based on an increasing number of empirical research and evidence that underlines the importance of legal and institutional frameworks in shaping women's rights and economic opportunities and improving gender equality. Includes data related to:

- accessing institutions, analyzing the legal capacity of women to interact with public authorities and those in the private sector similar to men;

- use of property, assesses the ability of women to access and use property;

- getting a job, studying the restrictions on women's work;

- providing incentives, analyzing income tax credits and available deductions for women in relation to men and providing childcare and education services;

- credit for buildings;

- access to court;

- Women's protection, examines the existence of legislation on domestic violence and sexual harassment.

In7 - LGBT rights (Equaldex, 2018)

LGBT rights refer to the acceptance of same-sex relationships, anti-discrimination related to power and legislation on their relations, and protection against hate crimes, as Javier Corrales says. Javier Corrales is Professor of Political Science at Amherst College, Amherst, Massachusetts. He obtained his Ph.D. in Political Science from Harvard University. He was a consultant for the World Bank, the United Nations, the Global Development Center, Freedom House, and the American Academy of Arts and Sciences. Country scores reflect the accepted rights for this segment of the population: homosexual activity, Same-sex marriage, Same-sex adoption, LGBT discrimination, LGBT employment discrimination, LGBT housing discrimination, Homosexuals serving openly in military, Equal age of consent, Blood donations by MSMs, Conversion therapy.

In8 - Financial inclusion (The World Bank, 2018)

This score is calculated using Global Findex (2014) and quantifies the possibilities to have accounts at an official institution. It measures the percentage of respondents holding an account with a bank, credit union, other financial institution, or post office, including respondents who have a debit card. 
In9 - Poverty rate (Eurostat, 2017b)

Occasionally referred to as "poverty risk", the relative poverty rate is defined as the share of people with an equivalent disposable income below the poverty threshold, set at $60 \%$ of the national median of equivalent disposable income (after social transfers). This definition of the conventionally agreed threshold based on statistical considerations. The relative poverty status cannot be eradicated, nor can it be considered as general, but may take more pronounced or attenuated forms, depending on the calculation of poverty rates compared to various others, more severe or "relaxed" than the standard one, of $60 \%$.

In10 - Corruption Perceptions Index (Eurostat, 2017c)

The Perception of Corruption Index launched in 1995 and is one of the most popular tools used by the Romanian Association for Transparency. Transparency International Romania/The Romanian Association for Transparency (TI-RO) is a non-governmental organization whose primary objective is to prevent and combat the phenomenon of corruption at national and international level, especially through research, documentation, information, education and awareness raising.

Computed on an annual, this is a composite index based on corruption data and reflects the opinion of business people and analysts around the world, including experts from the countries surveyed.

With a global average score of 43, in 2016 more than two-thirds of the 176 countries and territories for which the index was calculated fall below half of the scale (from 0 - very corrupt to 100 - very clean).

This result only highlights the link between corruption and inequality, and in too many countries people are deprived of their basic needs.

In11 - Rate of people who do not have access to adequate housing (Eurostat, 2017c)

The indicator is part of the indicator of "income and living conditions". This area covers four areas: people at risk of poverty or social exclusion, income distribution and money poverty, living and poverty conditions, which are again structured in collections of indicators on specific themes.

The "living conditions" framework includes indicators on the characteristics and living conditions of households, characteristics of the population as a function of various health and workplace irregularities, living conditions, as well as indicators related to childcare.

In12 - Employment rate of the population aged 15-64 (Eurostat, 2017d)

Employment is both a structural indicator and a short-term indicator.

Percentage of the employed population aged 15-64 in the total population of the same age, expressed as a percentage:

$$
R_{o}=\frac{P_{o_{15-64}}}{P_{t_{15-64}}} \times 100,
$$

where: $R_{o}$ - occupancy rate of the population aged 15-64; $P_{o_{15-64}}$ - the employed population aged $15-64 ; P_{t_{15-64}}$ - the total population aged $15-64$ years.

Goal: Measures employment on the labour market by age. It also reflects the labour market's ability to absorb labour.

Interpretation: The indicator provides information on the share of employed population by age group at national level, regional, gender, medium and the three major sectors of the national economy: agriculture, industry and construction, services. 


\begin{tabular}{|c|c|c|c|c|c|c|c|c|c|c|c|c|c|c|c|c|c|c|c|c|c|c|c|c|c|c|c|c|}
\hline$\Xi$ & $\hat{\imath}$ & $\widetilde{\sim}$ & 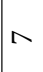 & $\sim$ & + & 6 & $\stackrel{\infty}{\sim}$ & $\stackrel{\infty}{\sim}$ & $\stackrel{\stackrel{2}{\sim}}{ }$ & 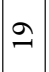 & $\widehat{\curvearrowright}$ & $\stackrel{\sim}{\sim}$ & $\vec{\sim}$ & $\exists$ & $a$ & $\stackrel{20}{=}$ & $\simeq$ & 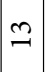 & $m$ & $\infty$ & 요 & 0 & $\stackrel{J}{\sim}$ & 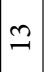 & $\approx$ & 으 & -1 & in \\
\hline$\Xi$ & 6 & $m$ & $\underset{\sim}{\sim}$ & 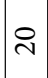 & 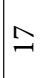 & 6 & 10 & $\stackrel{\sim}{\sim}$ & $\exists$ & $\exists$ & - & 0 & $\approx$ & 0 & $m$ & $\stackrel{\sim}{\sim}$ & $\stackrel{\bullet}{\sim}$ & $\stackrel{2}{-1}$ & -1 & $m$ & $\vec{\sim}$ & $\curvearrowright$ & $\widehat{\sim}$ & $\stackrel{\infty}{-}$ & 0 & $\exists$ & $\stackrel{\pi}{a}$ & $=$ \\
\hline $\bar{\Xi}$ & a & $\infty$ & $\stackrel{\infty}{\sim}$ & $\ddot{\sim}$ & 2 & 2 & -1 & $\exists$ & $\sim$ & $\approx$ & in & $\hat{\imath}$ & $\stackrel{\sharp}{\sim}$ & $\stackrel{\circ}{1}$ & $\stackrel{\sim}{\sim}$ & $\stackrel{\infty}{=}$ & 0 & in & 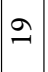 & 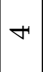 & 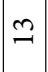 & 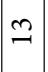 & $\stackrel{\sim}{\sim}$ & $\approx$ & $\stackrel{2}{2}$ & 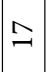 & $m$ & in \\
\hline$\Xi$ & $\infty$ & 으 & $\hat{\imath}$ & 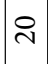 & $\cong$ & - & $m$ & $\ddot{\sim}$ & $\sim$ & 0 & 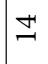 & $\approx$ & $a$ & $\approx$ & $\vec{\sim}$ & $\stackrel{\sharp}{\sim}$ & $\stackrel{\llcorner}{\sim}$ & $\Xi$ & \pm & + & $\stackrel{\infty}{\sim}$ & 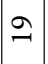 & $\stackrel{\infty}{\sim}$ & + & $\wedge$ & $\stackrel{\sim}{\sim}$ & 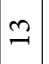 & $\exists$ \\
\hline$\stackrel{\infty}{\sharp}$ & $=$ & $n$ & $\hat{\sim}$ & $\vec{\sim}$ & $\triangleq$ & $\widetilde{\sim}$ & - & $\infty$ & - & $\beth$ & 6 & $\stackrel{\infty}{-1}$ & $\stackrel{\sim}{\sim}$ & $\stackrel{20}{2}$ & $\gtrsim$ & 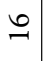 & $\tilde{\sim}$ & $\Xi$ & 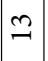 & + & $\stackrel{\leftrightarrow}{\sim}$ & 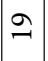 & $\stackrel{\infty}{\sim}$ & $\stackrel{\Perp}{\sim}$ & $\circ$ & $a$ & $m$ & in \\
\hline$\Xi$ & 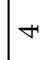 & r & $\stackrel{\sim}{\sim}$ & $\simeq$ & $\stackrel{\oslash}{\sim}$ & $\simeq$ & 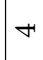 & $\stackrel{\sim}{\circ}$ & $\cong$ & $\nabla$ & $\simeq$ & $\simeq$ & $=$ & 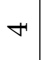 & $\underset{\sim}{\sim}$ & $\stackrel{\sim}{\circ}$ & ৩ & $n$ & $\approx$ & $\simeq$ & $\stackrel{\infty}{\sim}$ & - & $\stackrel{\sim}{\sim}$ & $\stackrel{๖}{\sim}$ & ㄱ. & - & $F$ & $r$ \\
\hline 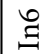 & 0 & $\cong$ & $\infty$ & $m$ & $\vec{\sim}$ & 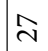 & $\vec{\sim}$ & $\underset{\sim}{ }$ & 0 & + & ন & $\Xi$ & $\Rightarrow$ & $\curvearrowright$ & $=$ & $\Xi$ & $\psi$ & $=$ & $\stackrel{\sim}{\sim}$ & $\vec{\sim}$ & $\stackrel{\infty}{\sim}$ & + & $\sim$ & F & + & - & $a$ & $a$ \\
\hline$\stackrel{\mathscr{\Omega}}{\Xi}$ & in & 10 & $\widehat{\curvearrowright}$ & $\stackrel{\sim}{\sim}$ & 으 & 으 & $\wedge$ & 으 & - & $\vec{\sim}$ & 으 & $\stackrel{2}{\sim}$ & $\hat{\sim}$ & $\curvearrowright$ & 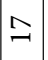 & $\ddot{\sim}$ & $\beth$ & - & $\curvearrowright$ & 4 & $\vec{\sim}$ & in & $\stackrel{2}{\sim}$ & 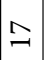 & 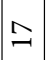 & 0 & -1 & $\stackrel{2}{\sim}$ \\
\hline$\stackrel{\sharp}{\Xi}$ & $\stackrel{2}{2}$ & - & $\hat{\sim}$ & 2 & $\approx$ & $\approx$ & - & $\simeq$ & - & $\simeq$ & $\curvearrowright$ & $\stackrel{2}{\sim}$ & $\stackrel{\infty}{\sim}$ & 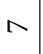 & $\approx$ & $\approx$ & $\simeq$ & $\approx$ & $\wedge$ & -1 & $\curvearrowright$ & $\wedge$ & $\stackrel{\sim 2}{\sim}$ & $\approx$ & $\wedge$ & $\simeq$ & -1 & - \\
\hline 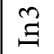 & $\approx$ & - & $\underset{\sim}{N}$ & $\stackrel{\sim}{\sim}$ & $\tilde{\sim}$ & $\cong$ & in & $\exists$ & $\sim$ & 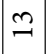 & $\vec{\sim}$ & 0 & $\stackrel{\infty}{-}$ & $\infty$ & શ & $a$ & $\stackrel{2}{2}$ & $\curvearrowright$ & $\stackrel{\sim}{2}$ & + & $\Xi$ & 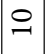 & $\stackrel{\infty}{\sim}$ & $\hat{\sim}$ & $\approx$ & $\curvearrowright$ & $n$ & 6 \\
\hline$\cong$ & in & $H$ & సี & $\cong$ & $\stackrel{20}{2}$ & $\cong$ & $\sim$ & $\stackrel{\sim}{\sim}$ & $m$ & - & a & $\exists$ & $\stackrel{\infty}{-}$ & $\stackrel{\Delta}{\sim}$ & $\wedge$ & $\hat{\imath}$ & $\stackrel{\sim}{\sim}$ & $\stackrel{2}{\sim}$ & $\approx$ & in & ㄱ. & $\simeq$ & $\stackrel{\sim}{\sim}$ & $\vec{\sim}$ & $\Xi$ & $\cong$ & $\infty$ & $\circ$ \\
\hline$\vec{\Xi}$ & $\approx$ & $\stackrel{0}{-1}$ & $\infty$ & $\stackrel{\sim}{\sim}$ & $\ddot{\sim}$ & a & $\vec{\sim}$ & $\exists$ & $\stackrel{\star}{\sim}$ & ㄱ. & $\dddot{m}$ & $\stackrel{\infty}{\sim}$ & $\curvearrowright$ & -1 & $\hat{\lambda}$ & $\simeq$ & $\curvearrowright$ & 6 & 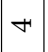 & $\stackrel{\infty}{-1}$ & $\sim$ & $\stackrel{\sim}{\sim}$ & in & $n$ & $\Xi$ & $\approx$ & $\circ$ & $\stackrel{n}{=}$ \\
\hline 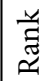 & $\stackrel{2}{2}$ & 6 & $\underset{\sim}{\mathbb{N}}$ & 0 & $\stackrel{10}{\sim}$ & in & 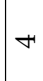 & $\stackrel{\sim}{\sim}$ & $\wedge$ & $\infty$ & ‡) & $\hat{\imath}$ & $\vec{\sim}$ & $a$ & 2 & $\tilde{\sim}$ & $\tilde{N}$ & $\exists$ & 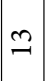 & $\sim$ & $\mid \Xi$ & $\infty$ & $\stackrel{\infty}{\sim}$ & $\simeq$ & 이 & 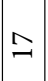 & -1 & $m$ \\
\hline 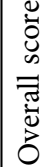 & 卓 & \begin{tabular}{l}
$2 \hat{n}$ \\
\multirow{\infty}{\infty}{}
\end{tabular} & $\begin{array}{l}\hat{n} \\
\tilde{n} \\
\end{array}$ & 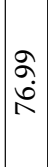 & م) & $\begin{array}{l}2 \\
0 \\
\infty \\
\infty\end{array}$ & $\begin{array}{l}\infty \\
\infty \\
\infty \\
\infty\end{array}$ & $\begin{array}{l}8 \\
0 \\
0\end{array}$ & $\begin{array}{l}n \\
1 \\
\infty \\
\infty \\
\infty\end{array}$ & $\begin{array}{c}\infty \\
0 \\
i \\
\infty \\
\infty\end{array} \mid$ & 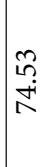 & $\begin{array}{l}0 \\
10 \\
0 \\
0\end{array}$ & $\begin{array}{l}\overrightarrow{n n} \\
\stackrel{+}{N}\end{array}$ & $\begin{array}{l}\overrightarrow{0} \\
i \\
\infty\end{array}$ & 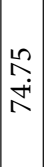 & $\begin{array}{l}N \\
N \\
N\end{array}$ & $\begin{array}{l}\hat{m} \\
\stackrel{+}{N}\end{array}$ & $\begin{array}{l}2 \\
2 \\
\bar{\lambda}\end{array}$ & $\stackrel{\overrightarrow{0}}{2}$ & $\begin{array}{l}0 \\
-2 \\
\infty\end{array}$ & $\begin{array}{l}+ \\
0 \\
\infty \\
\infty\end{array}$ & $\begin{array}{l}\infty \\
\infty \\
+ \\
\end{array}$ & $\begin{array}{l}f \\
\dot{b} \\
0\end{array}$ & $\begin{array}{l}2 \\
\hat{\Omega} \\
\end{array}$ & & 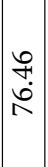 & 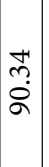 & $\begin{array}{l}\text { f̊t. } \\
\text { \& }\end{array}$ \\
\hline
\end{tabular}

จั้

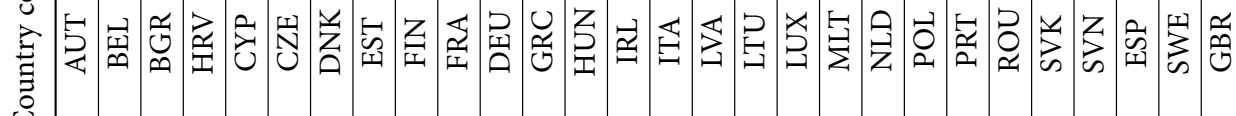
0

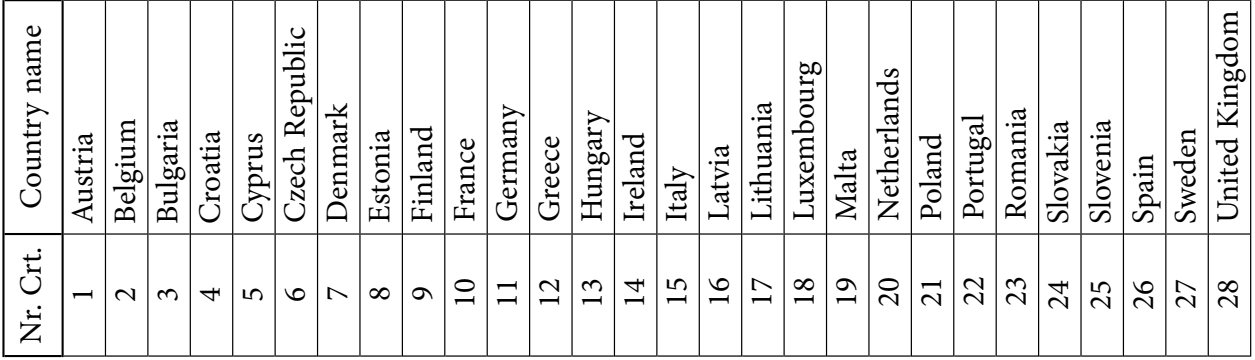




\begin{tabular}{|c|c|c|c|c|c|c|c|c|c|c|c|c|c|}
\hline \multirow{14}{*}{ 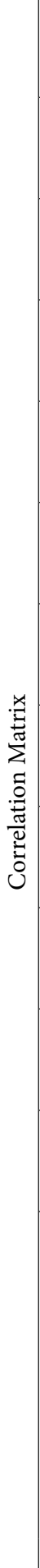 } & 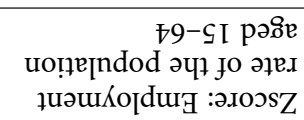 & $\stackrel{m}{\circ}$ & $\stackrel{\infty}{=}$ & $\stackrel{\vec{n}}{\overrightarrow{0}}$ & $\begin{array}{l}\hat{A} \\
\stackrel{0}{0} \\
0\end{array}$ & $\begin{array}{l}n \\
\stackrel{2}{0} \\
\circ \\
0\end{array}$ & $\left|\begin{array}{l}1 \\
\infty \\
\infty \\
0 \\
0\end{array}\right|$ & \begin{tabular}{l}
$\mathscr{0}$ \\
\hdashline \\
0 \\
0
\end{tabular} & $\begin{array}{l}2 \\
2 \\
0 \\
0 \\
1\end{array}$ & $\begin{array}{l}m \\
\Xi \\
\dot{1} \\
1\end{array}$ & 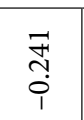 & $\begin{array}{l}0 \\
\stackrel{1}{1} \\
\stackrel{1}{0}\end{array}$ & ஓ̊ \\
\hline & 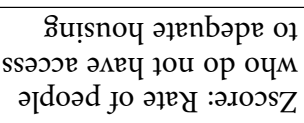 & ঐे & $\begin{array}{l}\text { ก̂ } \\
10 \\
e^{n}\end{array}$ & స̃ & 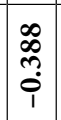 & $\begin{array}{c}\bar{\sigma} \\
\dot{\sigma} \\
\dot{i}\end{array}$ & ஸे & 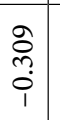 & $\begin{array}{l}-10 \\
0 \\
0 \\
0 \\
1\end{array}$ & $\begin{array}{l}0 \\
\mathbb{1} \\
0 \\
0 \\
0\end{array}$ & 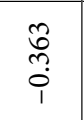 & §ִ & $\begin{array}{l}0 \\
\text { I } \\
\vdots \\
i\end{array}$ \\
\hline & 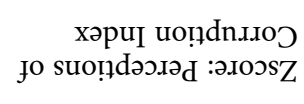 & 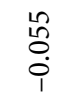 & $\begin{array}{l}\text { nิ } \\
\text { ñ. } \\
0\end{array}$ & $\begin{array}{l}\stackrel{\pi}{0} \\
\stackrel{0}{0}\end{array}$ & 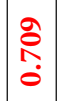 & $\begin{array}{l}m \\
\stackrel{n}{n} \\
0 \\
0\end{array}$ & $\begin{array}{l}\exists \\
\bar{n} \\
0 \\
i \\
1\end{array}$ & $\frac{\tilde{n}}{\sigma}$ & 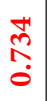 & $\begin{array}{c}n \\
\ddot{n} \\
0 \\
0 \\
1\end{array}$ & ஓ & $\begin{array}{l}\hat{n} \\
\tilde{m} \\
\dot{\rho}\end{array}$ & 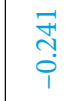 \\
\hline & 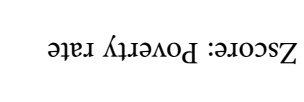 & $\ddot{0}$ & $\begin{array}{l}\infty \\
0 \\
+ \\
\substack{1 \\
1}\end{array}$ & 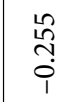 & 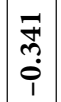 & 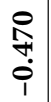 & 电 & $\mid \begin{array}{l}0 \\
0 \\
0 \\
0 \\
1\end{array}$ & $\underset{\substack{7 \\
\hdashline}}{\stackrel{1}{i}}$ & 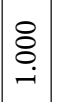 & 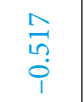 & $\begin{array}{l}\stackrel{0}{W} \\
\stackrel{W}{0} \\
0\end{array}$ & $\stackrel{m}{\rightrightarrows !}$ \\
\hline & $\begin{array}{r}\text { uọsnpou! } \\
\text { [е!̣uеu!̣ :ə.ıวs }\end{array}$ & $\stackrel{n}{n}$ & \begin{tabular}{c}
$\infty$ \\
\multirow{1}{10}{} \\
0
\end{tabular} & $\begin{array}{l}\hat{n} \\
\hat{n} \\
0\end{array}$ & 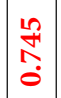 & $\begin{array}{l}\stackrel{e}{r} \\
\hat{\circ} \\
0\end{array}$ & 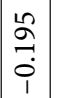 & $\frac{a}{\vec{j}}$ & 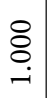 & \begin{tabular}{l}
$\hat{N}$ \\
\multirow{H}{*}{} \\
0 \\
1
\end{tabular} & 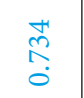 & $\begin{array}{l}\vec{\infty} \\
\stackrel{\infty}{0} \\
\dot{p}\end{array}$ & $\begin{array}{l}\text { La } \\
\text { ọ } \\
0\end{array}$ \\
\hline & 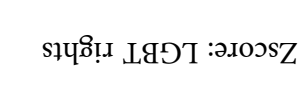 & ஸे & กิ? & ֻొ & స̊. & $\begin{array}{l}\infty \\
1 \\
n \\
0 \\
0\end{array}$ & $\begin{array}{c}10 \\
m \\
0 \\
0\end{array}$ & $\stackrel{8}{\circ}$ & 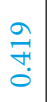 & $\begin{array}{l}0 \\
0 \\
0 \\
0 \\
1\end{array}$ & $\stackrel{n}{0}$ & $\begin{array}{l}\text { Oे } \\
\text { @़ } \\
\text { i }\end{array}$ & $\stackrel{\text { Oִ }}{0}$ \\
\hline & słપọ̊ț şuəuo & $\begin{array}{l}\stackrel{0}{\hat{~}} \\
\text { ஸे }\end{array}$ & 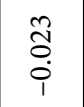 & $\begin{array}{l}\text { 능 } \\
\vdots \\
0 \\
1\end{array}$ & 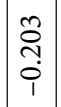 & \begin{tabular}{l}
+ \\
$\infty$ \\
\multirow{1}{*}{} \\
$i$
\end{tabular} & \begin{tabular}{l}
8 \\
\hdashline \\
\\
\end{tabular} & $\begin{array}{l}\stackrel{n}{n} \\
\tilde{m} \\
0\end{array}$ & $\begin{array}{l}n \\
\stackrel{2}{\sigma} \\
0 \\
1\end{array}$ & 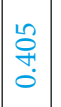 & $\underset{m}{\tilde{m}}$ & సิ & $\stackrel{0}{\infty}$ \\
\hline & 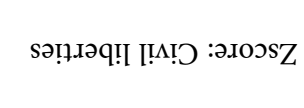 & $\begin{array}{l}\circ \\
0 \\
0 \\
1\end{array}$ & $\begin{array}{l}\infty \\
0 \\
0 \\
0\end{array}$ & ôt: & 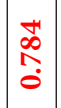 & $\begin{array}{l}8 \\
\\
\\
-\end{array}$ & $\left|\begin{array}{l}1 \\
\infty \\
0 \\
1 \\
0 \\
1 \\
1\end{array}\right|$ & $\begin{array}{l}\infty \\
1 \\
m \\
\vdots \\
0\end{array}$ & 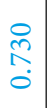 & 足 & $\begin{array}{l}\frac{n}{n} \\
\vdots \\
0\end{array}$ & +े & $\begin{array}{l}\text { Ln } \\
8 \\
0\end{array}$ \\
\hline & 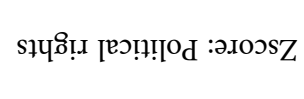 & $\begin{array}{l}\vec{n} \\
0 \\
0\end{array}$ & ஓ̣̊̊ & $\stackrel{9}{n}$ & $\underset{-}{8}$ & $\mid \begin{array}{l}+ \\
\infty \\
\infty \\
0 \\
0\end{array}$ & 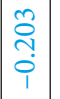 & 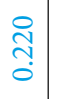 & 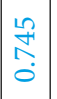 & $\begin{array}{l}\text { Fr } \\
\text { m. } \\
0 \\
1\end{array}$ & $\begin{array}{l}\stackrel{2}{\hat{2}} \\
\text { : }\end{array}$ & $\begin{array}{l}\infty \\
\infty \\
m \\
\vdots \\
1\end{array}$ & $\stackrel{1}{\hat{O}}$ \\
\hline & 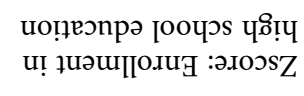 & 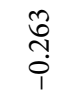 & ঙ̊? & ஓ & $\begin{array}{c}\stackrel{2}{n} \\
\tilde{\ln } \\
0\end{array}$ & 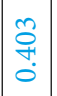 & $\mid$\begin{tabular}{c|}
2 \\
0 \\
0 \\
0 \\
1 \\
1
\end{tabular} & $\begin{array}{l}-\vec{\infty} \\
\infty \\
\vdots \\
0\end{array}$ & $\begin{array}{l}\hat{n} \\
\tilde{n} \\
0 \\
0\end{array}$ & $\mid \begin{array}{c}n \\
2 \\
n \\
\vdots \\
0 \\
1\end{array}$ & 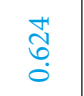 & స̂̀ & $\vec{m}$ \\
\hline & 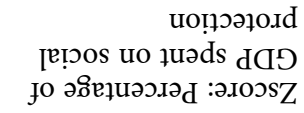 & $\begin{array}{l}0 \\
: \\
0 \\
i\end{array}$ & $\stackrel{8}{\stackrel{8}{\circ}}$ & ঙ̊? & \begin{tabular}{l}
8 \\
\hdashline \\
\hdashline \\
\hdashline \\
0
\end{tabular} & $\mid \begin{array}{l}\infty \\
0 \\
0 \\
0 \\
0\end{array}$ & 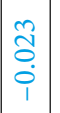 & $\begin{array}{c}\overrightarrow{1} \\
m \\
0 \\
0\end{array}$ & $\mid \begin{array}{c}\infty \\
2 \\
10 \\
0 \\
0\end{array}$ & \begin{tabular}{|l|}
$\infty$ \\
0 \\
0 \\
1 \\
0 \\
1
\end{tabular} \mid & $\begin{array}{l}0 \\
\text { nิ } \\
0 \\
0\end{array}$ & $\begin{array}{l}\text { ñ } \\
\text { กุ } \\
0 \\
0\end{array}$ & $\stackrel{\infty}{\exists}$ \\
\hline & 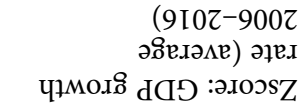 & ஓ̊ & 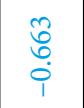 & 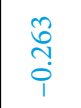 & $\begin{array}{l}\vec{m} \\
0 \\
\dot{0} \\
1\end{array}$ & $\left|\begin{array}{l|}0 \\
0 \\
0 \\
0 \\
1 \\
1\end{array}\right|$ & 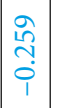 & $\begin{array}{l}-1 \\
\text { n } \\
0 \\
1 \\
1\end{array}$ & $\begin{array}{c}n \\
n \\
0 \\
0 \\
1\end{array}$ & $\begin{array}{l}\vec{n} \\
\dot{0} \\
\dot{0}\end{array}$ & $\begin{array}{l}20 \\
\stackrel{2}{0} \\
\stackrel{0}{1}\end{array}$ & ণั & ó \\
\hline & & 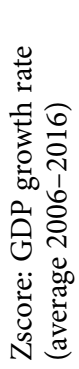 & 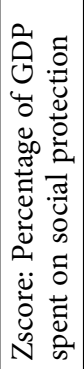 & 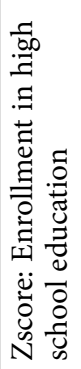 & 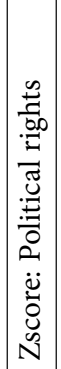 & 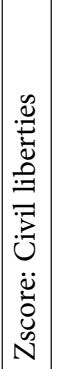 & 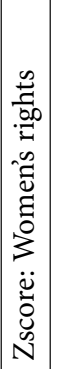 & 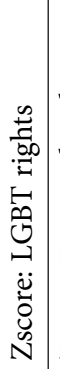 & 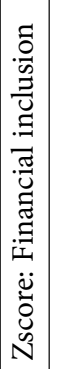 & 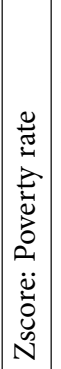 & 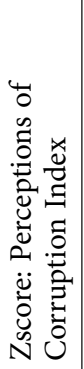 & 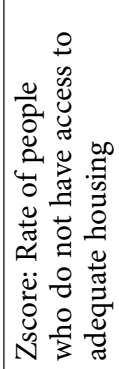 & 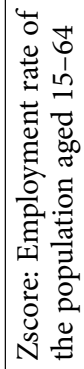 \\
\hline & & & & & & & & & & & & & \\
\hline
\end{tabular}

